\title{
DO POOR AND GOOD PERFORMING COMPANIES REPORT DIFFERENTLY? THE READABILITY AND IMPRESSION MANAGEMENT IN CORPORATE NARRATIVE DOCUMENTS: EVIDENCE FROM NORTHERN EUROPE
}

\author{
Oleh PASKO®1 ${ }^{*}$, Stanislaw MINTA ${ }^{\circledR 2}$, Serhii RUDENKO ${ }^{\circledR 3}$, Mykola HORDIYENKO®4 \\ ${ }^{1,4}$ Department of Accounting and Taxation, Sumy National Agrarian University, Sumy, Ukraine \\ ${ }^{2}$ Institute of Economic Sciences, Wroclaw University of Environmental and Life Sciences, Wroclaw, Poland \\ ${ }^{3}$ Department of Accounting and Audit, Kharkiv Petro Vasylenko National Technical University of Agriculture, \\ Kharkiv, Ukraine
}

Received 26 April 2020; accepted 27 May 2020

\begin{abstract}
The purpose of this paper is to assess the effect of financial performance on textual features of the CEO's statement. Specifically, given the incentives of poorly performed companies engage in impression management, the study investigates whether companies' reporting strategy hinges on its financial performance.

The research questions are tested through analysis of a variety of textual features in the CEO's statement of 30 good and 30 poor performed companies listed on NASDAQ OMX Stockholm. We apply a range of textual characteristics drawn mostly from prior studies in given realm to the specific research of impression management in the CEO's report. Overall our findings do not corroborate impression management claim, as six out of seven our results run counter to assertions made by impression management research. We found although evidence that poorly performed companies more focused on future compared with good performed companies. Finally, we conclude by discussing our results and outlining some avenues for further research.
\end{abstract}

Keywords: readability, obfuscation, annual reports, CEO’s statement, accounting narratives, impression management.

JEL Classification: M14, M40, M41, G34.

\section{Introduction}

The financial reporting is one of the main instruments of communicating financial information to intended users. Prerequisites of effective communication are adequate and understandable financial data as well as readily comprehendible narrative information (Courtis, 1995, 2004; Clatworthy \& Jones, 2001; Beattie et al., 2004; Linsley \& Lawrence, 2007; Li, 2008; Loughran \& Mcdonald, 2014; Luo et al., 2018).

The annual report has a significant influence on shareholders' as well as investors' attitude and assessment of whether to buy, keep, or sell stocks and with increasing international interest in corporate governance, it has gained importance over time. An annual report, in essence, consists of two parts: the financial statements' section, which is heavily regulated, and the narrative section, which is free from any elaborated regulations, and for this reason varies in length, depth and appearance (Beattie et al., 2004; Bhana, 2009; Brennan et al., 2009; Falschlunger et al., 2015). Accounting narratives are an increasingly significant part of the modern day's annual report. Research on accounting narrative is important as "narrative information equalled or exceeded the statutory financial information in the majority of annual reports" (Clatworthy \& Jones, 2001, p. 311).

Studies on financial reporting quality have focused mainly on earnings management (Beneish, 2001; Burgstahler \& Eames, 2006; Omar et al., 2014) and fraud (Rezaee, 2005; Hogan et al., 2008; Fleming et al., 2016). Nevertheless, companies also use a more inconspicuous variety of tools to influence outsiders' impressions of company performance and prospects, by manipulating the content and presentation of information in corporate documents with the aim "to present a self-serving view

${ }^{*}$ Corresponding author. E-mail: o.pasko@snau.edu.ua 
of corporate performance" (Brennan et al., 2009, p. 790). This practice in the accounting literature refers to as impression management (Clatworthy \& Jones, 2006; MerklDavies \& Brennan, 2007; Falschlunger et al., 2015).

There is a consensus that information asymmetry leads to the inefficient allocation of investment resources, adverse selection, insider trading and other negative outcomes (Verrecchia, 2001; Russell, 2015). There is panoply of research evidencing use of impression management in annual reports, showing that companies use narrative disclosures, especially the chairman's statement, to report news in a manner consistent with impression management (Subramanian et al., 1993; Courtis, 1998, 2004; Smith \& Taffler, 2000; Clatworthy \& Jones, 2001, 2006; Bloomfield, 2002, 2008; Beattie et al., 2004; Linsley \& Lawrence, 2007; Beattie et al., 2008; Li, 2008; Bhana, 2009; Lehavy et al., 2011; Merkl-Davies et al., 2011; Loughran \& Mcdonald, 2014; Falschlunger et al., 2015). "If managers engage in impression management, and if users are susceptible to it, then adverse capital misallocations may result" (MerklDavies \& Brennan, 2007).

Originally invented in psychology the term "impression management" depicts the process through which individuals attempt to control the impressions of others (Leary \& Kowalski, 1990; Wang, 2016). Applied to corporate reporting, the concept of impression management means that management selects information intended to be displayed and presents that information in such a way that distorts readers' perceptions of a company's accomplishments. Impression management mainly takes place in less regulated narrative disclosures which are used for interpreting financial information (Neu, 1991; Neu et al., 1998; Brennan et al., 2009).

Engagement in impression management means that companies management "seek to convey a more favourable impression of the organization than is warranted" (Beattie et al., 2008, p. 183). The prior literature shows that impression management widely occurs in annual reports (Clatworthy \& Jones, 2006, p. 494). Some researchers even state that corporate collapses were a combination of fraud and impression management (Clatworthy \& Jones, 2006; Davidson et al., 2004). Impression management can be understood as an inclination from the part of individuals or organizations towards selective data use, thus positively presenting themselves. However, one should not assume at once that impression management is a result of conscious actions, as it may arise as a result of deliberate or subliminal processes (Clatworthy \& Jones, 2006, p. 494). However, most studies implicitly assume conscious behaviour (Merkl-Davies \& Brennan, 2007).

It is also worth to stress different word usage at play: "Disclosure" and "Narrative" (Beattie, 2014). "Disclosure" studies are widespread in North America and based on economic information asymmetry arguments and agency theory, whereas "narrative" research began to appear mainly in Europe and focused on finding the fundamental role of narrative in creating subjective meaning for human actors (Beattie, 2014).
There are several content analysis methods applied in analysing accounting narratives from an impression management point of view: Syntactical manipulation, Rhetorical manipulation, Attribution of organisational outcomes, Thematic manipulation, Selectivity, Performance comparisons (Merkl-Davies \& Brennan, 2007; Brennan et al., 2009).

Narrative information that supplements quantitative financial reporting content is of great significance as it represents a key part of information transfer from preparers to users. However, how useful that information depends on its readability and obfuscation (Courtis, 1998).

Academic research into accounting narratives can be broadly divided into two categories: content analysis studies and readability research (Clatworthy \& Jones, 2001, p. 311). As of today research into accounting narratives broadly defined covers a broad spectrum interrelated topics starting from big data styles positivist quantitative analyses, includes quantitative content analysis supported by theory from the social sciences and reaches out the other research pole - qualitative case studies that uses discourse methodologies from the humanities discipline (Merkl-Davies et al., 2011; Beattie, 2014). Our research more tends to the second and third directions listed above.

The studies so far have been focused on the various regions (Northern America, Asia and Oceania), but we did not come across any research using this approach focused on Northern Europe. Furthermore, our approach distinctive from others in using so-called a multi-method research approach in readability, in which Flesch readability easy is only one component of the readability analysis (Stone \& Parker, 2016). In our research, we are going to complement it with such indicators as the length of report, frequency of passive sentences, personal references and other intending to assess to the fullest possible extent all known forms of impression management. On top of that one of the novelty points of our research lay in utilizing novel technics that although is in its infancy allow with the high level of reliability to establish the gender of the person who prepared the text. Unavailable earlier this technics allow shedding a light on the issue who really write CEO's statements. So we believe that this combination of new geographical location analysed, methodological breadth and novel technics use constitute a solid level of contribution to the field that would qualify this paper for readers' attention and would capture their interest.

The purpose of this paper is to assess the effect of financial performance on textual features of the CEO's statement. Specifically, given the incentives of poorly performed companies engage in impression management, the study investigates whether companies' reporting strategy hinges on its financial performance. Our main research question could be laid dawn as follows: Do poor and good performing companies report differently?

The research questions are tested through analysis of a variety of textual features in the CEO's statement of 30 good and 30 poor performed companies listed on NASDAQ OMX Stockholm. We apply a range of textual 
characteristics drawn mostly from prior studies in given realm to the specific research of impression management in the CEO's statement.

The article is structured as follows. In the second and third section, we successively depict the evolution of research into accounting narrative from readability and obfuscation to impression management. In the fourth section, we develop the hypothesis analysing the prior findings on the topic. This is followed by a hypothesis construction section. A brief overview of sample selection and methodology is given in the sixth section of the paper. The seventh section is dedicated to the main part - findings and we conclude with discussions and conclusion section.

\section{Readability and obfuscation research in accounting}

An increasing body of research in accounting and finance scrutinizes whether and to what extent qualitative attributes of corporate communication (like tone, readability) influence decision-making by investors and information intermediaries. The central question all readability studies address is "how difficult are annual reports to read?" (Linsley \& Lawrence, 2007, p. 621) The hypothesis is that negative performance is reported differently using language that is more difficult to read (Brennan et al., 2009). All early studies on this topic came to the conclusion that the readability of annual reports is low because they are difficult to read. All previous explanations for differences in readability have been attributed to the difference between profitable and unprofitable companies (Clatworthy \& Jones, 2001; Courtis, 2004; Linsley \& Lawrence, 2007). Accordingly, a significant difference in the ease of reading different segments of narrative information has traditionally been regarded as the manifestation of obfuscation (Clatworthy \& Jones, 2001; Courtis, 2004; Rutherford, 2016).

Prior studies counted a variety of various readability measures applied in readability research: Fog, Flesch, Kwolek, Dale-Chall, Lix, Fry, Cloze, Texture index, Transitivity index and Diction (Brennan et al., 2009, p. 795). While one researcher estimated the number of technics used at 10 (Brennan et al., 2009), others reported back in 1979 that there are "now no fewer than fifty-three readability formulae in all" (Barnett \& Leoffler, 1979, p. 58). The preponderance of Flesch easy reading formula is though unquestioned as it is widely used as first preference choice. Flesch reading ease rating uses $0-100$ scale there score under 50 is related to the text difficult to read (Table 1).

Although some current studies use also Fog index (Lo et al., 2017; Lim et al., 2018), we detected also application of FRE readability measure (Moffitt \& Burns, 2009), texture index (Sydserff \& Weetman, 1999, p. 475), Cloze procedure (Adelberg, 1979; Smith \& Taffler, 1992), Lix (Smith \& Taffler, 1992), Flesch Fog, Lix (Courtis, 1995), the Gunning measure of readability (Heath \& Phelps, 1984), C-Test, the MIT test and the The Science Virtual Test SVT test (Jones \& Smith, 2014).
Table 1. Flesch reading ease ratings / assessment (Courtis, 1995)

\begin{tabular}{|c|l|l|l|}
\hline $\begin{array}{c}\text { Reading } \\
\text { ease } \\
\text { score }\end{array}$ & \multicolumn{1}{|c|}{ Difficulty } & \multicolumn{1}{|c|}{$\begin{array}{c}\text { Educational } \\
\text { level }\end{array}$} & $\begin{array}{c}\text { Typical } \\
\text { magazine style }\end{array}$ \\
\hline $0-30$ & Very Confusing & Postgraduate & Scientific \\
\hline $30-50$ & Difficult & Undergraduate & Academic \\
\hline $50-60$ & Fairly difficult & Grade $10-12$ & Quality \\
\hline $60-70$ & Standard & Grade $8-9$ & Digest \\
\hline $70-80$ & Fairly ease & Grade 7 & Slick fiction \\
\hline $80-90$ & Easy & Grade 6 & Pulp fiction \\
\hline $90-100$ & Very easy & Grade 5 & Comic \\
\hline
\end{tabular}

However, further based on the basic predictions of the readability theories, researchers began to raise questions on why variability in readability occurs? That is where "the translation of readability to obfuscation" as Rutherford calls it happened (2016). This transition from assessing relative readability rather than absolute readability occurred (Clatworthy \& Jones, 2001, p. 313) and as a result took place the translation of readability to obfuscation (Rutherford, 2016). The intra-study readability or the readability of different sections of the same annual report was used to prove the tendency of management to mislead the readers in the case when they are trying to hide some salient point of company's activities. As some author pointed out "annual reporting is viewed as an exercise in obfuscation" (Bhana, 2009, p. 33).

Obfuscation in the simplest way is understood as variability in readability (Clatworthy \& Jones, 2001; Rutherford, 2016). But there is a growing body of studies insisting on including in the scope of obfuscation use of other manipulation technics (Moreno \& Casasola, 2016). As Moreno \& Casasola put it "transparency might be unrelated to readability" (Moreno \& Casasola, 2016, p. 27). Brennan et al. believe that obfuscation it is when management "makes linguistic choices and uses rhetorical devices to conceal negative firm performance" (Brennan et al., 2009, p. 795). Sydserff and Weetman think that obfuscation assumes that management "is not neutral in its presentation of narrative information and will seek to obfuscate failures or bad news disclosure" (2002, p. 536). Li writes that "managers have incentives to obfuscate information when firm performance is poor because the market may react with a delayed incorporation of the information contained in complicated disclosures" (2008, p. 228). Thus obfuscation hypothesis always presupposes a negative relation "between a firm's current performance and its annual report's level of complexity" (Li, 2008, p. 224).

\section{Impression management}

An inclination to appear better and polish information to high gloss may not be in itself something bad and perverted (Courtis, 2004). However, when it comes to financial reporting this inclination may pose a serious and 
sometimes insurmountable obstacle to the neutral and unbiased presentation of information. There is a risk, when "polishing" information, to slip into deliberately misleading on results. As Clatworthy and Jones appropriately noticed there is always a risk that this "benign understandable human attribute" would morph into something that violates the basics of Anglo-Saxon financial reporting, namely that accounts should be "fairly presented (US) and show a true and fair view (UK)" (2006, p. 494).

Leary and Kowalski have conceptualized impression management as a 2-component model composed of 2 discrete processes: 1) impression motivation and 2) impression construction (1990). Impression motivation is conceptualized as a function of 3 factors: the goal-relevance of the impressions one creates, the value of desired outcomes, and the discrepancy between current and desired images. Leary and Kowalski believe that five factors determine the impressions people try to construct: the self-concept, desired and undesired identity images, role constraints, target's values, and current social image (1990).

Merkl-Davies and Brennan (2007) have developed the framework of impression management behaviour. Based on managerial self-serving motives and tactical situation managers, authors believe, can choose 1) concealment or 2) attribution. Concealment, in turn, could be of two types: either 1) obfuscation of bad news or 2) emphasis on good news. Then combination of various types of information and types of manipulation used gives according to Merkl-Davies and Brennan (2007) in total six impression management strategies used for concealment: 1) reading easy manipulation; 2) rhetorical manipulation; 3) thematic manipulation; 4) visual and structural manipulation; 5) performance comparisons; 6) choice of earning numbers and one - attribution of performance - used for attribution.
Similar list of the content analysis methods applied in analysis of accounting narratives from an impression management point of view is given by Brennan et al. (2009): 1) syntactic manipulation, 2) rhetorical manipulation, 3) attribution of organisational outcomes (meaning-orientated studies), 4) thematic manipulation (form-orientated studies), 5) selectivity (choice/selection of performance number), 6) visual/presentation effects (emphasis), and 7) performance comparisons.

The theoretical foundation for our research provides five theories (Table 2) which explicate the behaviour of preparers: agency theory; signalling theory; legitimacy theory; stakeholder theory; and institutional theory (Merkl-Davies \& Brennan, 2007)

On the whole, taking into account all criteria there is a distinctive gulf between agency theory and signalling theory on one side and legitimacy theory, stakeholder theory and institutional theory on the other.

\section{Hypothesis development}

Prior researches on CEO' statements have demonstrated that it is widely used among private as well as institutional investors (Smith \& Taffler, 1992; Clatworthy \& Jones, 2006). It is widely acknowledged that CEO's statement is the most read part of annual reports (Jones, 1988; Kohut \& Segars, 1992; Courtis, 1995, 2004; Mäkelä \& Laine, 2011). The CEO's statement is believed to influence the decision-making process of users (Segars \& Kohut, 2001; P. Stanton \& J. Stanton, 2002). Although contrary to financial reports, CEO's statements by itself rarely contain any solid quantitative number to build on the decisions, but they help to frame the financial information (Aerts, 2001, 2005; Courtis, 2004; Merkl-Davies et al., 2011).

Table 2. Five theories explicating what incentivize preparers to engage in impression management (prepared by authors based on Merkl-Davies \& Brennan, 2007)

\begin{tabular}{|l|l|l|l|}
\hline \multicolumn{1}{|c|}{ Theory } & \multicolumn{1}{|c|}{ Explanation } & $\begin{array}{c}\text { Audience for } \\
\text { disclosures }\end{array}$ & $\begin{array}{c}\text { Concepts of } \\
\text { performance }\end{array}$ \\
\hline $\begin{array}{l}\text { Agency } \\
\text { theory }\end{array}$ & $\begin{array}{l}\text { The unsatisfied organizational results could lead to a conflicting situation } \\
\text { between shareholders and managers. To avoid this managers opting to engage in } \\
\text { manipulation of outsiders' perception and consequently decisions made based on } \\
\text { financial reporting. }\end{array}$ & $\begin{array}{l}\text { Investors } \\
\text { performancial }\end{array}$ \\
\hline $\begin{array}{l}\text { Signalling } \\
\text { theory }\end{array}$ & $\begin{array}{l}\text { Contrary to the agency theory focused on poorly performing companies, signalling } \\
\text { theory applied to well performing firms. The managers of successful companies, } \\
\text { signalling theory postulates signal their superiority by providing a higher level of } \\
\text { transparency in narrative sections of annual reports and presentation of information. }\end{array}$ & Investors & $\begin{array}{l}\text { Financial } \\
\text { performance }\end{array}$ \\
\hline $\begin{array}{l}\text { Legitimacy } \\
\text { theory }\end{array}$ & $\begin{array}{l}\text { According to legitimacy theory disclosures can change the perceptions about the } \\
\text { legitimacy of the organization. Mostly though this theory deals with social and } \\
\text { environmental disclosures. }\end{array}$ & $\begin{array}{l}\text { Society, } \\
\text { Stakeholders }\end{array}$ & $\begin{array}{l}\text { Social and } \\
\text { environmental } \\
\text { performance }\end{array}$ \\
\hline $\begin{array}{l}\text { Stakeholder } \\
\text { theory }\end{array}$ & $\begin{array}{l}\text { Stakeholders theory similarly to legitimacy theory as it considers the corporate } \\
\text { reporting as a response to the demands and expectations of stakeholders (customers, } \\
\text { employees, governmental agencies, NGOs, lobby groups, etc.). }\end{array}$ & $\begin{array}{l}\text { Society, Stakeholders } \\
\text { Social and } \\
\text { environmental } \\
\text { performance }\end{array}$ \\
\hline $\begin{array}{l}\text { Institutional } \\
\text { theory }\end{array}$ & $\begin{array}{l}\text { This theory assumes that companies on its own cannot withstand pressure and } \\
\text { conform to institutional expectations through adoption of institutional norms. } \\
\text { Consequently, managers are responding to institutional pressures in corporate } \\
\text { reporting. }\end{array}$ & $\begin{array}{l}\text { Society, } \\
\text { Stakeholders }\end{array}$ & $\begin{array}{l}\text { Social and } \\
\text { environmental } \\
\text { performance }\end{array}$ \\
\hline
\end{tabular}


Annual report narratives such as CEO's statement are a vehicle to emphasis details and add up specifics to numbers within a wider explanatory context and this framing of accounting results with narrative may boost investor's confidence in the company (Aerts, 2001, 2005). Narrative document, in essence, is the place where interpretations are put on facts and the latter are presented within the broader context or the framing, lens - how senior manager read the situation (Aerts, 2005). Furthermore, annual reports users relay on non-financial, qualitative and accounting information while making the decision and if this information "infected" with biased impression management, it is probable that it would mislead users, who ended up with erroneous decision (Breton \& Taffler, 2001; Yan et al., 2019).

Prior researches have resulted in varying findings. Courtis in his study found that all 120 annual reports "displayed statistical variability in the readability of the Chairman's Address" (Courtis, 1998, p. 468). The coefficients of variation ranged from 4.83 per cent to 89.64 per cent, with 86 per cent of companies having a $\mathrm{V}$ in excess of 10 per cent. The sample mean coefficient was 25.87 per cent. Author's conclusion: "Variability of readability is pervasive" (Courtis, 1998, p. 468). Although later in the study Courtis retracted himself stating that "the overall conclusion from this study together with the 1998 findings (Courtis) is that by-and-large there is no systematic evidence to indicate that obfuscation is being used as a tool to deliberately deceive readers" (Courtis, 2004, p. 308)

Later though Clatworthy and Jones (2001) in the study of CEO's letters of 30 profitable and 30 unprofitable UK company failed to support Courtis' obfuscation hypothesis. Clatworthy and Jones claimed that contrary to Courtis' assumption "the managerial obfuscation is not a determinant of readability variability" and that "Courtis assumes an excessive degree of sophistication on behalf of managers in the communication of accounting narratives" (Clatworthy \& Jones, 2001, p. 323). Authors proposed one possible explanatory element which has been so far omitted in the accounting readability literature - "the thematic structure underpinning the narrative" (Clatworthy \& Jones, 2001, p. 323).

In their later study, Clatworthy and Jones (2006) investigated the effect of financial performance on the textual characteristics of the chairman's statement of 50 highly profitable and 50 highly unprofitable listed UK companies. Authors reported pervasive impression management use what manifested in "differential patterns of reporting in the chairman's statement contingent upon whether the companies are profitable or unprofitable" (Clatworthy \& Jones, 2006, p. 506). Clatworthy and Jones (2006, p. 506) found that "compared with profitable companies, unprofitable companies focus less on key financial indicators, use fewer quantitative results, fewer personal references and more passive sentences, and focus more on the future".

Abrahamson and Park (1994) have found that change in company's financial performance had an impact on the number of negative words in the president's letters: the greater the decline in the financial performance of the company, the greater was the disclosure of negative outcomes in the annual narratives (Abrahamson \& Park, 1994). Abrahamson and Park (1994, p. 1329) results were also consistent with the claim that "accountants and certain types of shareholders and directors prompt officers to reveal negative outcomes, whereas others promote concealment". They also found evidence for the claim that "some concealment and its toleration by outside directors may be intentional" (Abrahamson \& Park, 1994, p. 1329).

In the later paper, Abrahamson and Amir (1996) found that the information presented in the president's letter was at par with financial information in the annual reports (such as a change in sales, earnings levels divided by stock price, book rate of return). These results suggest in authors own words that "the president's letter contains useful information about the future of the company and not just about past performance. Our findings emphasize the importance of non-financial information relative to the widely used financial information such as earnings and book values" (Abrahamson \& Amir, 1996, p. 1179).

Sydserff and Weetman (2002, p. 536) also find the higher readability score in the CEO's statement of good performers, when compared to poor performers "based on the longer-term performance measures" and believe that their findings "support the obfuscation hypothesis, namely that management is not neutral in its presentation of narrative information and will seek to obfuscate failures or bad news disclosure".

Li examined the relation between annual report readability (using Fog Index) and firm performance and earnings persistence (Li, 2008). Li's two main findings are. First, "annual reports of firms with poor performance are more difficult to read. The effect is statistically (but not economically) significant" (Li, 2008, p. 244). Second, "the profits of firms with annual reports that are easier to read are more persistent. The effect is economically significant: an inter-quartile change in annual readability has about the same impact on profit persistence as do accruals" ( $\mathrm{Li}$, 2008, p. 244).

Keusch et al. (2012) investigated the attributional content in the letter to shareholders of Europe's largest listed companies in a crisis year and a non-crisis year. Their findings are that "during a crisis, management has a greater tendency to engage in self-serving behaviour than in a non-crisis year" (Keusch et al., 2012, p. 644).

Hadro et al. (2017, p. 325) in recent years in European context (Poland) found that "the choice of impression management techniques by companies in Poland being driven by their current ownership situation and financial performance, rather than by a communication strategy". Quite simply what they found is that the more concentrated ownership is, the shorter the CEO's letters are, which in turn is indicative that management invests less effort in communicating with investors (Hadro et al., 2017). Contrary to it, the CEO's letters of companies owned by foreign shareholders are longer (Hadro et al., 2017). 
The similar thread of argumentation we find in the next study. Aerts and Yan (2017, p. 404) came up with the proposition that incentives for rhetorical impression management are, on average, stronger in the USA than in the UK and found that "rhetorical impression management is stronger in US companies".

Aerts and Yan (2017, pp. 424-425) classified rhetorical coping behaviour based on linguistic style features in three dominant categories: 1) an acclaiming or assertive stance, 2) a defensive framing position and a more detached, 3) logic-based cognitive impression management orientation. Those rhetorical profiles "differently... affect the overall readability of the narrative" (Aerts \& Yan, 2017, p. 426)

Asay et al. (2018, p. 380) found that bad news disclosures are less readable than good news, but only "when managers have a stronger self-enhancement motive".

All abovementioned studies came to different conclusions, but not attempted to abnegate this research direction altogether. This attempt was made by Rutherford who, himself belonging to this group of researchers (Rutherford, 2003, 2005), armed with Latour's Actor-network theory unleashed a scathing attack on "obfuscation failed project" (2016). Rutherford criticised the researchers who with "a narrow range of research instruments" failed so far to establish some consensus on the issue while the "outcomes are predominantly negative and, where positive, are sometimes so only at the $5 \%$ level and invariably with an extremely small coefficient of determination" (Rutherford, 2016, p. 69).

So far the field responded with recognising "the potentially considerable value in combining objective formulaic readability analysis with subjective proxies and supplementary measures of readability and reader accessibility is an important starting point" and that "the imprimatur of leading accounting communications scholars is persuasive" to this approach (Stone \& Parker, 2016).

Research on impression management in CEOs statements is important due to the following rationales. First, the CEO statement is a part of annual report widely used among investors (Courtis, 2004; Clatworthy \& Jones, 2006; Mäkelä \& Laine, 2011; Allee \& Deangelis, 2015; Wang, 2016). Second, some study found that content of the CEO's statement has an impact upon investors' decision-making (Segars \& Kohut, 2001). Third, since CEO statements unaudited the probability of inappropriate altering of information in it grows (Clatworthy \& Jones, 2001, 2006). Fourth, CEO’s statement is an important indicator of financial performance and keywords as well as narrative themes in CEO's statements are valuable to discern in the company either bankrupt or financially robust firm (Smith \& Taffler, 1995, 2000; Clatworthy \& Jones, 2006). Fifth, it is especially helpful for private investors, who are the least likely to see through impression management tactics in annual reports (Elliott, 2006).

\section{Hypothesis construction}

As prior studies show us the CEO's statements are of great importance to investors and broad users in their decisionmaking as it frames and complements financial reports. Nevertheless, this usefulness will degrade in the case when managers are inclined and incentivised to report favourable information and suppress unfavourable and resort to language tricks to enhance their public impression. So, we test the following general null hypothesis:

H1: There are no systematic differences in the readability of different passages taken from the chairman's statement.

We test this hypothesis using three passages of 100 words in length taken from the front, middle and end of the CEO's statements of 60 companies (30 good performers and 30 poor performers). We test those passages against each other and against the mean of the overall passage.

We use so-called a multi-method research approach in readability, in which Flesch readability easy is only one component of the readability analysis (Stone \& Parker, 2016). In our research, we are going to complement it with such indicators as the length of report, frequency of passive sentences, personal references and other intending to assess a broader range of impression management manifestation.

H2: The CEO's statements of "good performers" and "poor performers" will be similar in length.

Here we follow Li who believes that "because the information-processing cost of longer documents is presumed to be higher, assuming everything else to be equal, longer documents seem to be more deterring and more difficult to read" (Li, 2008, p. 225). So our assumption is that good performer will have shorter CEO's statements compared to poor performers.

Clatworthy and Jones (2006, p. 500) who also tested similar hypothesis rejected it and found that "profitable companies were no more verbose than unprofitable companies" and "unprofitable companies' chairman's statements were marginally longer (mean of 901 versus 827 words and 2.13 pages versus 2.07 pages)".

H3: The CEO's statements of "good performers" and "poor performers" will contain a similar number of passive sentences.

The passive voice is inferred used for those occasions when "the writer finds it advantageous to distance himself or herself from the message" (Thomas, 1997, p. 53) and that "active voices are associated with success, while passive voices distance writers from the message" (Clatworthy \& Jones, 2006, p. 496). Sydserff and Weetman (2002, p. 527) distinguish two strategies: 1) the movement of the "agent phrase" from the start to the end of the sentence, and 2) the omission of the agent phrase, but whichever strategy is employed, "the agent behind the action is downplayed".

So, our expectation in regards to this hypothesis is that companies from good performers group to prefer active 
rather than passive sentences in their narratives and vice versa.

Test conducted by Clatworthy and Jones (2006, p. 501) in their study found that profitable companies use 25.8 per cent passive sentences, but unprofitable companies use 26.8 per cent, although the difference is marginal and not significant in two-tailed t-tests $(\mathrm{p}=0: 648)$.

H4: The CEO's statements of "good performers" and "poor performers" will contain a similar number of personal references.

Our expectation is that good performer company will be more likely to use personal references than poor performers as latter will undertake actions to distance themselves from the bad news. For example, Thomas, who proposed a marvellous interpretation of phrases from annual reports, found a positive link between the uses of the pronoun 'we' and company's performance (Thomas, 1997). Clatworthy and Jones found that "profitable companies are significantly more likely than unprofitable companies to use personal references overall (19.06 references versus 14.02 references; $\mathrm{p}=0.073$ )" (2006, p. 501).

H5: The CEO's statements of "good performers" and "poor performers" will contain a similar number of key financial indicators.

In testing this hypothesis we expect that good performer company will be more willing to use key financial variables (profit, sales, dividends and earnings per share) and expose them to a wider public as they have no incentives whatsoever to hide it. However, managers of those companies who performed poorly according to agency theory will be incentivised to distract users from bad news and use as less as possible references to key financial indicators.

For example, Beattie and Jones (2000) found that companies are more likely to include graphs of key financial variables when their profit has increased. Melis and Aresu (2019) found "a selective display of key performance indicators, which is an important concern in corporate communication and reporting" and Moreno et al. (2019) use of "qualitative textual characteristics with a self-serving bias, but did not use those with a more quantitative character". In prior study's findings are that " 92 per cent of profitable companies mentioned at least one key financial variable compared to 86 per cent of unprofitable companies" (Clatworthy \& Jones, 2006, p. 503)

H6: The CEO's statements of "good performers" and "poor performers" will contain a similar number of quantitative references.

What we expect in regards to $\mathrm{H} 6$ is that successful companies "to use "hard" quantitative references rather than "soft" qualitative discussion when reporting their results" (Clatworthy \& Jones, 2006, p. 499). Some authors

Table 3. Summary of the paper's hypothesis (source: developed by authors)

\begin{tabular}{|c|c|c|c|}
\hline Hypothesis & $\begin{array}{l}\text { What is tested } \\
\text { according to } \\
\text { classification at } \\
\text { (Brennan et al., } \\
\text { 2009) }\end{array}$ & $\begin{array}{l}\text { What is tested } \\
\text { according to } \\
\text { classification at } \\
\text { (Clatworthy \& Jones, } \\
\text { 2006) }\end{array}$ & Measurement indicators \\
\hline $\begin{array}{l}\mathrm{H}_{1}: \text { There are no differences in the } \\
\text { readability of different passages taken } \\
\text { from the chairman's statement }\end{array}$ & $\begin{array}{l}\text { Syntactical } \\
\text { manipulation, } \\
\text { Obfuscation }\end{array}$ & Syntactical measures & $\begin{array}{l}\text { The readability (Flesch and Fog) of } \\
\text { three different passages } 100 \text { words in } \\
\text { length taken from the front, middle } \\
\text { and end of the CEO's statements. }\end{array}$ \\
\hline $\begin{array}{l}\mathrm{H}_{2} \text { : The CEO's statements of "good } \\
\text { performers" and "poor performers" will } \\
\text { be similar in length. }\end{array}$ & $\begin{array}{l}\text { Rhetorical } \\
\text { manipulation }\end{array}$ & Syntactical measures & $\begin{array}{l}\text { The length of the CEO's statements in } \\
\text { words. }\end{array}$ \\
\hline $\begin{array}{l}\mathrm{H}_{3} \text { : The CEO's statements of "good } \\
\text { performers" and "poor performers" will } \\
\text { contain a similar number of passive } \\
\text { sentences. }\end{array}$ & $\begin{array}{l}\text { Rhetorical } \\
\text { manipulation }\end{array}$ & Syntactical measures & $\begin{array}{l}\text { The number of sentences with passive } \\
\text { voice }\end{array}$ \\
\hline $\begin{array}{l}\mathrm{H}_{4} \text { : The CEO's statements of "good } \\
\text { performers" and "poor performers" will } \\
\text { contain a similar number of personal } \\
\text { references. }\end{array}$ & $\begin{array}{l}\text { Rhetorical } \\
\text { manipulation }\end{array}$ & Syntactical measures & $\begin{array}{l}\text { The number of singular personal } \\
\text { references: I, ME, MY and plural } \\
\text { personal references WE, OUR, US } \\
\text { used. }\end{array}$ \\
\hline $\begin{array}{l}\mathrm{H}_{5} \text { : The CEO's statements of "good } \\
\text { performers" and "poor performers" will } \\
\text { contain a similar number of key financial } \\
\text { indicators. }\end{array}$ & $\begin{array}{l}\text { Attribution of organi- } \\
\text { sational outcomes and } \\
\text { Performance com- } \\
\text { parisons }\end{array}$ & $\begin{array}{l}\text { Aspects of } \\
\text { presentation }\end{array}$ & $\begin{array}{l}\text { The number of references to the key } \\
\text { financial variables: 1) Profit before } \\
\text { tax; 2) Sales; 3) Earnings per share; } \\
\text { 4) Dividends; 5) Cash flow }\end{array}$ \\
\hline $\begin{array}{l}\mathrm{H}_{6} \text { : The CEO's statements of "good } \\
\text { performers" and "poor performers" will } \\
\text { contain a similar number of quantitative } \\
\text { references. }\end{array}$ & & $\begin{array}{l}\text { Aspects of } \\
\text { presentation }\end{array}$ & $\begin{array}{l}\text { The number of quantitative references } \\
\text { to percentages (increase/decrease in } \\
\text { profits) and to monetary amounts } \\
\text { (absolute value of profits/losses) }\end{array}$ \\
\hline $\begin{array}{l}\mathrm{H}_{7} \text { : The CEO's statements of "good } \\
\text { performers" and "poor performers" will } \\
\text { focus equally on the future. }\end{array}$ & $\begin{array}{l}\text { Meaning-orientated } \\
\text { thematic studies }\end{array}$ & $\begin{array}{l}\text { Aspects of } \\
\text { presentation }\end{array}$ & $\begin{array}{l}\text { The percentage of text in the CEO's } \\
\text { statement discussing the future }\end{array}$ \\
\hline
\end{tabular}


Table 4. Descriptive statistics of study's sample

\begin{tabular}{|l|c|c|c|c|c|c|c|c|}
\hline \multirow{2}{*}{} & \multicolumn{7}{|c|}{ Good performers } \\
\cline { 2 - 10 } & $\mathrm{n}$ & Mean & Median & StDev & Minimum & Maximum & Q1 & Q3 \\
\hline Net Income, in millions, SEK & 30 & 7746 & 941 & 25840 & 60 & 141828 & 162 & 3949 \\
\hline $\begin{array}{l}\text { Net income of the reporting year to } \\
\text { the net income of the previous year, } \%\end{array}$ & 30 & 323.1 & 202.3 & 447.9 & 139.8 & 2546.3 & 154.4 & 260.1 \\
\hline & \multicolumn{7}{|c|}{} & \multicolumn{7}{|c|}{ Poor performers } & -35206 & 6682 & -392 & 1550 \\
\hline Net Income (loss), in millions, SEK & 30 & -561 & 82 & 6850 & -352 & 78.5 & -74.2 & 67.7 \\
\hline $\begin{array}{l}\text { Net income of the reporting year to } \\
\text { the net income of the previous year, } \%\end{array}$ & 30 & -75.3 & 26.1 & 386.3 & -2051.6 & 7 & 7 \\
\hline
\end{tabular}

presented evidence that managers are more likely to disclose good news in hard quantitative references, whereas bad news tends to be disclosed as qualitative statements (Skinner, 1994).

H7: The CEO's statements of "good performers" and "poor performers" will focus equally on the future.

In regards to $\mathrm{H} 7$ we anticipate that successful companies will focus less on the future due to the fact that current favourable data are to be discussed. Poorly performed firms though deprived of pleasant current news will be more inclined to cast an eye on the future. Kohut and Segars (1992) put a similar hypothesis forward but failed to find corroborating evidence. Later Clatworthy and Jones (2006, p. 504) on the example of UK companies found that "unprofitable companies' narratives (73.9 words per chairman's statement) emphasise the future much more than profitable companies (53.2 words per chairman's statement). This difference in emphasis is significant at the 0.10 level $(\mathrm{p}=0.055)$ ".

For convenience sake, we gather all hypothesis and the measurement indicators they match in Table 3.

\section{Sample selection and methodology}

Our idea was to analyse the current financial performance and whether it prompts any changes in systematic differences in the readability of different passages taken from the CEO's statement of "good performers" and "poor performers". Our population consisted of companies included in OMX Nordic 40 and OMX_Nordic_Large_Cap_EUR_ GI indexes on NASDAQ OMX Stockholm. Then we eliminated from the sample all financial sector companies to get homogenous set of companies.

Our sample consists of 60 firm-year observations, among them 30 good performers and 30 poor performers. So we selected only 30 top performed companies and 30 companies who ended up at the bottom of the pecking order in terms of financial performance. We changed our erstwhile intention to test profitable vs. unprofitable companies due to the lack of unprofitable companies to fill out our 30 companies quote and we tacked our approach to test instead good vs. poor performers.

Two criteria were used for the selection of enterprises. First, it is the net income of the enterprise. The second criterion we have considered is the dynamics of net income through time. For this purpose, the ratio of net income of the reporting year to the net income of the previous year was compared. This second criterion representing dynamic characteristic well complements a static one - first, because the dynamics of the financial condition is also a very important indicator considers by many exchange and financial world dwellers. At the beginning, we also expected to include the ratio of the actual financial result to the expected by analysts, but the lack of accurate information forced us to abandon this idea and we ended up with two criteria: net income in the reporting year and the ratio

Table 5. The list of companies analysed in the study*

\begin{tabular}{|l|l|}
\hline \multicolumn{1}{|c|}{ Poor performing } & \multicolumn{1}{|c|}{ Good performing } \\
\hline A.P. MØLLER - MÆRSK & AHLSELL \\
2016 & AHLSTROM-MUNKSJÖ OYJ \\
ALK-ABELLO & BOLIDEN \\
AMER SPORTS OYJ & BONAVA A \\
ARJO B & DSV \\
AUTOLIV SDB & ELEKTA B \\
CARLSBERG & ESSITY \\
CITYCON OYJ & EVOLUTION GAMING \\
ERICSSON & GROUP \\
FABEGE & FINNAIR OYJ \\
FLSMIDTH \& CO. & FISKARS OYJ ABP \\
HUFVUDSTADEN A & FORTUM \\
KINNEVIK 2016 & JM \\
LATOUR & KESKO OYJ A \\
LUNDBERGFÖRETAGEN B & KINDRED GROUP \\
LUNDIN PETROLEUM 2016 & KONECRANES OYJ \\
METSO & METSÄ BOARD OYJ A \\
MILLICOM INT. CELLULAR & MUNTERS GROUP \\
2016 & NETCOMPANY GROUP \\
MODERN TIMES GROUP & NOBIA \\
2016 & NOLATO B \\
NCC A & ØRSTED \\
NOKIA 2016 & OUTOKUMPU OYJ \\
NOKIA 2017 & SANDVIK \\
RATOS 2016 & SCA A \\
SANOMA & SEB \\
SCHOUW \& CO. & SSAB A \\
SKANSKA B & SWEDISH ORPHAN \\
SWEDISH MATCH & BIOVITRUM \\
TELE2 2016 & TELIA COMPANY \\
TERVEYSTALO OYJ & UPONOR OYJ \\
TRELLEBORG B & VALMET OYJ \\
WALLENSTAM B & \\
\hline NOte: - bY defaul th preVaIn & \\
\hline
\end{tabular}

Note: ${ }^{*}$ - by default the prevalence of cases is 2017 reporting year, if otherwise it is stated explicitly. 
of the net income in the reporting and preceding it year. Data was collected directly through the exchange's website http://www.nasdaqomxnordic.com.

During the first stage of the selection we singled out those companies that had a net loss for any of the two years 2016 and 2017 (the study was done in the spring of 2019 , so it was the last two years available at that moment). In the second stage, after the elimination of unprofitable companies, we applied the second criterion, according to which we selected the remaining companies to form two groups of companies: poor and good performers. Descriptive statistics of our sample is given in Table 4.

The list of companies' analysed divided in two groups is presented in Table 5 .

In our research, we use Readable.io service to test hypothesis 1-5 and NVivo 11 software for hypothesis 6-7. All statistical analysis was done using Minitab 17.

Each CEO's statement was downloaded for web-sites of companies, and then we methodically delineated it to be fit for testing.

\section{Findings}

The reveof our findings would be appropriate to start with a variety of names used by companies to title their head report to investors and the wider public (Figure 1). Three main titles for the chief officer of companies used (in descending order): CEO, President and Chairman and various synonyms used to name the report: comments, statement, review, letter, massage and even interview.

Overall, as a brief overview preceding detailed explanation, we should state that we have confirmed all but one out of seven tested hypotheses. We failed to confirm the hypothesis concerning concentration on the future in the CEO's statements.

Hypothesis 1. Our first hypothesis stated that there were no systematic differences in the readability of different passages taken from the chairman's statement. We used two proxies for readability: Flesch Reading Ease (Table 6) and Gunning Fog index (Table 7).

Flesch Reading Ease scores for both good and poor performers hovers around 40 , which indicates a high level of reading difficulty (Table 6). Our results are congruent

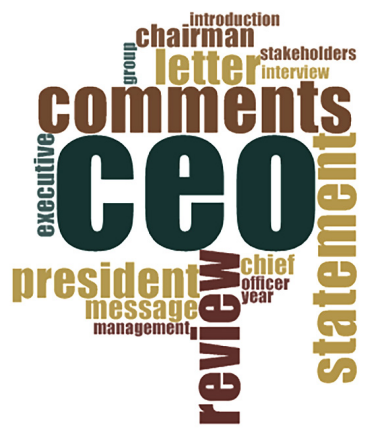

Figure 1. Word cloud depicting the frequency of words used in titles of CEO's reports of sample companies (both poor and good performers, $\mathrm{n}=60$ ) (created by authors)
Table 6. Obfuscation Flesch reading ease (source: developed by authors)

\begin{tabular}{|l|c|c|c|c|c|}
\hline Passage & $\begin{array}{c}\text { Good } \\
\text { performers } \\
(\mathrm{n}=30)\end{array}$ & $\begin{array}{c}\text { Poor } \\
\text { performers } \\
(\mathrm{n}=30)\end{array}$ & $\begin{array}{c}\text { Total } \\
(\mathrm{n}=60)\end{array}$ & $\begin{array}{c}\mathrm{F} \\
\text { value }\end{array}$ & $\begin{array}{c}\mathrm{P} \\
\text { value }\end{array}$ \\
\cline { 2 - 6 } & 1 & 2 & 3 & 4 & 5 \\
\hline First & 39.06 & 40.50 & 39.78 & 0.20 & 0.658 \\
\hline Middle & 35.11 & 34.45 & 34.78 & 0.05 & 0.816 \\
\hline Last & 39.84 & 40.45 & 40.15 & 0.05 & 0.831 \\
\hline $\begin{array}{l}\text { Mean } \\
\text { of three } \\
\text { passages }\end{array}$ & 38.00 & 38.47 & 38.235 & - & - \\
\hline $\begin{array}{l}\text { Whole } \\
\text { state- } \\
\text { ment }\end{array}$ & 39.13 & 39.97 & 39.550 & 0.33 & 0.569 \\
\hline $\begin{array}{l}\text { ANOVA } \\
\text { results }\end{array}$ & $\mathrm{F}=2.95$ & $\mathrm{~F}=1.36$ & $\mathrm{~F}=4.13$ & - & - \\
\cline { 2 - 6 } & $\mathrm{P}=0.058$ & $\mathrm{P}=0.263$ & $\begin{array}{c}\mathrm{P}= \\
0.018\end{array}$ & - & - \\
\hline
\end{tabular}

with prior research findings revealing the high level of reading difficulty in narrative corporate documents (e.g. Subramanian et al., 1993; Courtis, 1995; 1998; Clatworthy \& Jones 2001; Courtis, 2004).

We run tests for differences between the first passage, middle passage, final passage, mean of the three passages and the overall chairman's statement within the Good performers group $(\mathrm{P}=0.058, \mathrm{~F}=2.95)$, Poor performers group $(\mathrm{P}=0.263, \mathrm{~F}=1.36)$ and total for both groups $(\mathrm{P}=$ $0.018, \mathrm{~F}=4.13)$.

We then conducted analysis of variance test (good vs. poor performance) separately for the means of first passage $(P=0.658, F=0.20)$, middle passage $(P=0.816, F=$ $0.05)$ and last passage $(\mathrm{P}=0.831, \mathrm{~F}=0.05)$. Thus, $\mathrm{H} 1$ is confirmed.

From all this information, however worth paying attention is the difference between the readability of different passages for the entire sample $(\mathrm{P}=0.018, \mathrm{~F}=4.13)$. Although it is not the distinction between poor and good performers, it shows us that middle passages in CEO statements are the most difficult to read. This can be explained by the fact that middle passages are exactly where as a rule the technical information is laid down. We emphasize however that although it is important it is in no way related to our main task - to find the distinction among poor and good performers.

We run as well analysis of variance test based on readability measured through Gunning Fog index (Table 7).

Analysis of variance test (good vs. poor performance) separately for the means of first passage $(\mathrm{P}=0.193, \mathrm{~F}=$ $1.73)$, middle passage $(P=0.516, F=0.43)$ and last passage $(P=0.347, F=0.516)$ returned no significant results. Thus, $\mathrm{H} 1$ with readability proxy Gunning Fog index is as well confirmed.

Hypothesis 2. The premise we build our second hypothesis on is that the cost of processing longer documents is higher. Therefore, assuming everything else to be 
Table 7. Obfuscation gunning fog index (source: developed by authors)

\begin{tabular}{|l|c|c|c|c|c|}
\hline \multirow{2}{*}{ Passage } & $\begin{array}{c}\text { Good } \\
\text { performers } \\
(\mathrm{n}=30)\end{array}$ & $\begin{array}{c}\text { Poor } \\
\text { performers } \\
(\mathrm{n}=30)\end{array}$ & $\begin{array}{c}\text { Total } \\
(\mathrm{n}=60)\end{array}$ & $\begin{array}{c}\mathrm{F} \\
\text { value }\end{array}$ & $\begin{array}{c}\mathrm{P} \\
\text { value }\end{array}$ \\
\cline { 2 - 6 } & 1 & 2 & 3 & 4 & 5 \\
\hline First & 14.895 & 16.009 & 15.452 & 1.73 & 0.193 \\
\hline Middle & 16.021 & 16.488 & 16.255 & 0.43 & 0.516 \\
\hline Last & 15.412 & 16.026 & 15.719 & 0.90 & 0.347 \\
\hline $\begin{array}{l}\text { Mean } \\
\text { of three } \\
\text { passages }\end{array}$ & 15.443 & 16.174 & 15.808 & & \\
\hline $\begin{array}{l}\text { Whole } \\
\text { state- } \\
\text { ment }\end{array}$ & 15.553 & 15.883 & 15.718 & & \\
\hline $\begin{array}{l}\text { ANOVA } \\
\text { results }\end{array}$ & $\mathrm{F}=1.59$ & $\mathrm{~F}=0.21$ & $\mathrm{~F}=1.21$ & - & - \\
\cline { 2 - 6 } & $\mathrm{P}=0.209$ & $\mathrm{P}=0.810$ & $\mathrm{P}=0.299$ & - & - \\
\hline
\end{tabular}

Table 8. The length of CEOs statements of "good performers" and "poor performers" (source: developed by authors)

\begin{tabular}{|c|c|c|c|c|c|}
\hline & Mean & Minimum & Median & Maximum & Mode \\
\hline $\begin{array}{l}\text { GP } \\
\text { Length }\end{array}$ & 1046.1 & 457.0 & 1076.5 & 2469.0 & 1099 \\
\hline \begin{tabular}{|l} 
PP \\
Length
\end{tabular} & 1264 & 424 & 1181 & 3557 & 1023 \\
\hline \multirow{2}{*}{$\begin{array}{l}\text { ANOVA } \\
\text { results }\end{array}$} & $\mathrm{F}=2.71$ & & & & \\
\hline & $\mathrm{P}=0.105$ & & & & \\
\hline $\begin{array}{l}\text { Paired } \\
\text { T-test }\end{array}$ & $\mathrm{P}=0.083$ & & & & \\
\hline
\end{tabular}

equal, "longer documents seem to be more deterring and more difficult to read" (Li, 2008, p. 225). So, we expect that companies with losses, or with less-than-expected profit, would write annual reports with long sentences and more words. The null hypothesis we tested though suggests similarity in length.

Although CEO statements of poor performers are longer on average about 200 words compared to those companies marked as good performers, this difference is not significant $(\mathrm{P}=0.105, \mathrm{~F}=2.71 \mathrm{ANOVA})$ and $\mathrm{P}=0.083$ Paired T-test (Table 8).

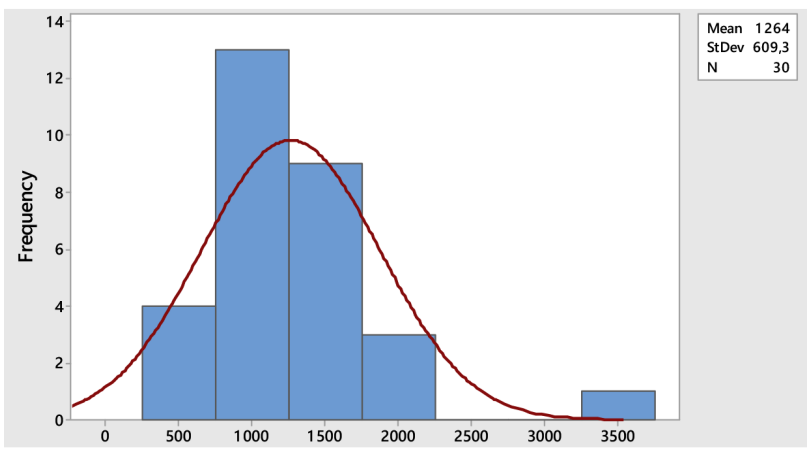

Figure 2. Length of CEO statements of poor performers, words (source: developed by authors)

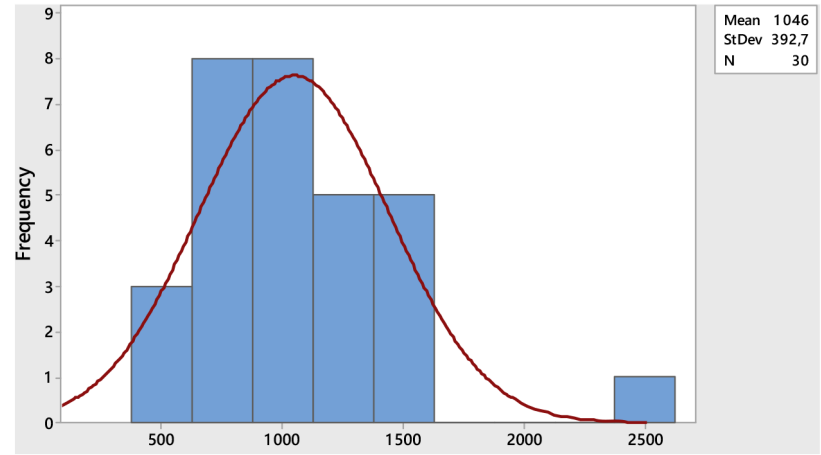

Figure 3. Length of CEO statements of good performers, words (source: developed by authors)

Nevertheless, as Figures 2 and 3 reveal among GP companies only a few have CEO statements longer 1500 words, while in the group of poor performers close to $1 / 3$ of companies produced CEO narrative about 2000 words long.

Worth noting is also the fact that the longest, as well the shortest statements were produced by CEO (or whatever level technical specialist prepared them) of companies classified as poor performers. In the first instance, it suits well for our hypothesis, while in the second one it runs counter rationale enclosed in the hypothesis. Thus, $\mathrm{H} 2$ is confirmed.

Hypothesis 3. The CEO's statements of "good performers" and "poor performers" will contain a similar number of passive sentences. The passive voice is widely believed used for those occasions when "the writer finds it advantageous to distance himself or herself from the message" (Thomas, 1997, p. 53) and that "active voices are associated with success, while passive voices distance writers from the message" (Clatworthy \& Jones, 2006, p. 496)

Table 9. The number of passive sentences in the CEO's statements of "good performers" and "poor performers" (source: developed by authors)

\begin{tabular}{|c|c|c|c|c|c|}
\hline & Mean & Minimum & Median & Maximum & Mode \\
\hline $\begin{array}{l}\text { GP } \\
\text { passive }\end{array}$ & 5.67 & 0.00 & 5.00 & 23.00 & 4 \\
\hline \begin{tabular}{|l|} 
PP \\
passive
\end{tabular} & 7.23 & 0.00 & 6.00 & 43.00 & 7 \\
\hline \multirow{3}{*}{$\begin{array}{l}\text { ANO- } \\
\text { VA } \\
\text { results }\end{array}$} & $\mathrm{F}=0.92$ & & & & \\
\hline & $\mathrm{P}=0.342$ & & & & \\
\hline & $\begin{array}{c}\text { R-sq = } \\
1.56 \%\end{array}$ & & & & \\
\hline
\end{tabular}

ANOVA results $(\mathrm{P}=0.342, \mathrm{~F}=0.92)$ helped us to confirm H3 (Table 9).

Hypothesis 4. The CEO's statements of "good performers" and "poor performers" will contain a similar number.

The data clearly indicate that there are no differences in frequency the personal references used in CEO statements between poor performers and good performers companies (Table 10). Thus, that gives us green light to confirm the hypothesis 4 . 
Table 10. The number of personal references in the CEO's statements of "good performers" and "poor performers" (source: developed by authors)

\begin{tabular}{|c|c|c|c|c|c|c|}
\hline & \multicolumn{2}{|c|}{ Good performers $(\mathrm{n}=30)$} & \multicolumn{2}{|c|}{ Poor performers $(\mathrm{n}=30)$} & \multicolumn{2}{|c|}{ ANOVA results } \\
\hline & Mean & StDev & Mean & StDev & $\mathrm{P}$ & $\mathrm{F}$ \\
\hline \multicolumn{7}{|c|}{ First person singular } \\
\hline I & 3.033 & 2.553 & 2.833 & 3.152 & 0.788 & 0.07 \\
\hline $\mathrm{Me}$ & 0.2333 & 0.5040 & 0.1000 & 0.3051 & 0.220 & 1.54 \\
\hline My & 0.367 & 0.615 & 0.633 & 1.299 & 0.314 & 1.03 \\
\hline Total singular & 3.633 & 3.113 & 3.567 & 4.125 & 0.944 & 0.00 \\
\hline \multicolumn{7}{|c|}{ First person plural } \\
\hline Our & 29.33 & 14.76 & 30.13 & 15.07 & 0.836 & 0.04 \\
\hline Us & 2.833 & 2.183 & 3.333 & 3.241 & 0.486 & 0.49 \\
\hline We & 25.70 & 13.67 & 26.40 & 14.29 & 0.847 & 0.04 \\
\hline Total plural & 57.87 & 27.15 & 59.87 & 29.33 & 0.785 & 0.08 \\
\hline Total personal references & 61.50 & 27.75 & 63.43 & 30.57 & 0.798 & 0.07 \\
\hline
\end{tabular}

Table 11. The number of key financial indicators in the CEO's statements of "good performers" and "poor performers" (source: developed by authors)

\begin{tabular}{|l|c|c|c|c|c|c|}
\hline \multirow{2}{*}{} & \multicolumn{2}{|c|}{ Poor performers $(\mathrm{n}=30)$} & Good performers $(\mathrm{n}=30)$ & \multicolumn{2}{|c|}{ ANOVA results } \\
\cline { 2 - 7 } & Mean & StDev & Mean & StDev & P & F \\
\hline PROFIT BEFORE TAX & 1.0000 & 0.000000 & 1.000 & 0.830 & 1.000 & 0.00 \\
\hline SALES & 0.533 & 1.074 & 0.867 & 0.860 & 0.190 & 1.76 \\
\hline EPS EARNINGS PER SHARE & 0.0667 & 0.2537 & 0.1333 & 0.3457 & 0.398 & 0.72 \\
\hline DIVIDENDS & 0.433 & 0.626 & 0.367 & 0.615 & 0.679 & 0.17 \\
\hline CASH FLOW & 0.1333 & 0.3457 & 0.3000 & 0.4661 & 0.121 & 2.47 \\
\hline ANY & 1.200 & 1.186 & 1.033 & 1.066 & 0.569 & 0.33 \\
\hline
\end{tabular}

Table 12. The number of quantitative references in the CEO’s statements of "good performers" and "poor performers" (source: developed by authors)

\begin{tabular}{|l|c|c|c|c|c|c|}
\hline \multirow{2}{*}{} & \multicolumn{2}{|c|}{ Poor performers $(\mathrm{n}=30)$} & Good performers $(\mathrm{n}=30)$ & \multicolumn{2}{c|}{ ANOVA results } \\
\cline { 2 - 7 } & Mean & StDev & Mean & StDev & P & F \\
\hline Monetary references & 2.633 & 2.798 & 2.533 & 2.240 & 0.879 & 0.02 \\
\hline Percentage references & 2.833 & 3.130 & 3.500 & 2.980 & 0.402 & 0.71 \\
\hline
\end{tabular}

Hypothesis 5. The CEO's statements of "good performers" and "poor performers" will contain a similar number of key financial indicators.

Although none from the tested items did reach the rejection level for null hypothesis, the closest to it came number of times sales figures $(\mathrm{P}=0.190)$ were mentioned and closely related to it cash flow figures $(\mathrm{P}=0.121)$ (Table 11). Overall though nothing in our results testing $\mathrm{H} 5$ manifest any sort of differences between poor performed firms and those that performed well. Thus, H5 in confirmed too.

Hypothesis 6. The CEO's statements of "good performers" and "poor performers" will contain a similar number of quantitative references. ANOVA results as for monetary references $(P=0.879, F=0.02)$ as well as for percentage references $(\mathrm{P}=0.402, \mathrm{~F}=0.71)$ helped us to confirm H6 (Table 12).
Hypothesis 7. The CEO's statements of "good performers" and "poor performers" will focus equally on the future. Our expectations concerning this hypothesis are that the narrative of good performed companies will focus more on current results than on future ones in an attempt to signal their efficiency. Contrary to the attitude of good performers those who performed poorly are looking more in the future since present does not have anything to boast about and attract investors (or at least to prevent the sale out of shares).

Our approach to testing this hypothesis was as follow. We marked all future-looking sentences at CEO statements in Nvivo11 environment and enlisted the help of software to calculate the percentage of those sentences in the whole statements. This approach yielded those results (Table 13). 
Table 13. The focus on the future in the CEO's statements of "good performers" and "poor performers" (source: developed by authors)

\begin{tabular}{|c|c|c|c|c|c|c|}
\hline & \multicolumn{2}{|c|}{ Poor performers $(\mathrm{n}=30)$} & \multicolumn{3}{|c|}{ Good performers $(\mathrm{n}=30)$} & \multicolumn{2}{|c|}{ ANOVA results } \\
\cline { 2 - 7 } & Mean & StDev & Mean & StDev & P & F \\
\hline Future references, $\%$ & 19.18 & 13.20 & 7.194 & 5.277 & 0.000 & 21.33 \\
\hline
\end{tabular}

Our results do not confirm hypothesis 7 as $\mathrm{P}=0.000$ and $\mathrm{F}=21.33$. Thus, $\mathrm{H} 7$ is rejected. In simple language, it means that there is a significant difference in the per cent of future-oriented rhetoric in CEO statements of poor and good performed companies. Exactly as we expected poor performed companies predominantly look in the future in an attempt to obfuscate their undesirable and often disappointing fruits of today (Figure 4).

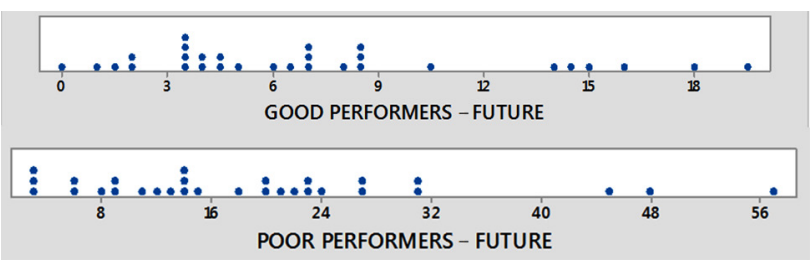

Figure 4. Distribution of companies on the percentage of future-oriented rhetoric in CEO statements, \% (source: developed by authors)

Several firms from poor performer's category went so far that approximately half the content of their head officers addresses narrated something that is to come instead of what has been achieved in reporting period. In average $1 / 5$ of the content of poorly performed firms is focused on future, whereas in good performer category future related references are something that complements the story about the achieved results (not standalone future talk) and makes on average only 7.1 per cent.

The perennial issue is who stays behind preparing the CEO's comments (Beattie et al., 2004; Beattie, 2014). It is often assumed that rarely it is a work of CEO themselves; rather it is done by clerks and only approved and corrected by the CEO. But until recently it is only the spying was the reliable method to find out the truth. However, now readiable.io allows identifying the gender of a person who has written the text. Although this technology is still in its infancy (accuracy of about 70\%) it could provide us with a glimpse (still blurred one) into the issue who in fact prepares the CEO's statements. We compared the gender of the company's $\mathrm{CEO}$ and gender of the person who wrote the text according to the assessment of readiable.io and found discrepancies in 18 out of all 60 cases. In a group of good performers in 11 out of 30 cases, the gender did not match, in the group of poor performers - in 7 out of 30 cases.

We think that this technology and our first approach to assess those discrepancies open up a whole new dimension in impression management research. When we reliably can confirm the claim about the involvement of other than CEO itself people, then it is the company's strategy, not an individual person. That is not a big deal in itself, but looking at it through the lens of impression management it lifts impression management from the realm of unconscious to the domain of strategy and politics.

\section{Discussions and conclusions}

Our study investigates readability and impression management practice of 30 good performed and 30 poor performed companies listed on NASDAQ OMX Stockholm. We have confirmed all, but one hypothesis. We couldn't say that we found a differential pattern of reporting in the CEO's statements depending on whether the company performs good or poor.

Overall our findings do not corroborate impression management claim, as six out of seven our results run counter to assertions made by impression management research. There are no differences in the readability of different passages taken from the chairman's statement in good and poor performed companies, reports are similar in length, contain a similar number of passive sentences, personal references, key financial indicators and quantitative references. Our results though show that there is a significant difference in the per cent of future-oriented rhetoric in the CEO's statements of poor and good performed companies. We interpret it in a way congruent with our expectations promulgated in hypothesis: poor performed companies predominantly look in the future in an attempt to obfuscate their undesirable and often disappointing fruits of today, whereas good performers have something to brag about in present and feel no need to project their look in the future.

The fact that six out of the seven results are not pointing to the direction of impression management and that others authors came to the opposite findings (Clatworthy \& Jones, 2006; Li, 2008) bags the questions why is it so? One possible and very plausible indeed explanation is that due to the insufficient number of unprofitable companies we corrected our first preference approach - analyse profitable versus unprofitable companies - and instead pursued less contrasted approach in which we compared good versus poor performers. As a result of that according to the agency theory manager's incentives of poorly performed companies to engage in impression management were not as strong as they would have been in the case when financial performance of those companies deteriorated further and was in red. At the same time, we believe that the gulf between profitable and unprofitable companies was sufficiently enough to put in the motion the mechanism of impression management and to compel managers of less fortunate companies to act. 
Furthermore, the motivation to engage in impression management is in part driven by discrepancies between desired and current results (Bolino et al., 2016). For example, if the company had the goal to reach net income totalling 0.5 million and ended the year with a net income slightly over the naught when we classified it as poorly performed while in the eyes of managers it has just a little bit missed its target. Since we did not take to account that aspect (the difference between desired and current results) we may have overlooked it, but since we did not come across any study taking into account this dimension we believe that it is a proper topic for further research. Although in our study, given that we eliminated from the sample all financial sector companies and a had pretty homogenous bunch of companies, we went from the assumption that market competition would compel managers as well as shareholders more than some imaginary internal goals set often not in arm's length circumstances.

Although in our opinion it is less credible justification, but one reason that our study failed to find evidence of persistence impression management might be this famous Nordic mentality (Telseth \& Halldorsson, 2019) and unique mindset which prefer integrity, modesty, a sense of community over greed, individualism and the desire to cheat and circumvent rules.

We also do not reject altogether Rutherford's assumption that "project concerned with accounting narrative obfuscation" is failing "because of its inability to adapt sufficiently to accommodate the interests of its constituents" (2016, p. 57). Rutherford contrasted "accounting narrative obfuscation" project with "readability per se" project which, in his opinion, "did see a successful reconfiguration of actors' interests" (2016, p. 57). In other words, Rutherford admits that there are readability issues in narrative reports, but this phenomenon is in not for the purpose to obfuscate the text and is not the result of intentional action taken by managers and that we should stop conflate understandability and readability (Rutherford, 2016).

Additional future research is required to understand more clearly the connection between desired (expected) and actual results and how does it incentivize the managers to resort to using of impression management tools. Yet, only after we had conclusive evidence that impression management exists on an institutional level in companies (something we failed to establish) - another promising strand of future research.

\section{Author contributions}

CRediT author statement: Oleh PASKO: Conceptualization, Methodology, Supervision, Writing- Reviewing and Editing, Project administration; Stanislaw MINTA: Writing-Original draft preparation, Investigation; Serhii RUDENKO: Investigation, Data Curation; Mykola HORDIYENKO: Investigation, Data Curation. Authorship recognition process was guided by the Vancouver Protocol on authorship.

\section{Disclosure statement}

We know of no conflict of interest associated with this publication, and there has been no significant support for this work that could have influenced outcome.

\section{References}

Abrahamson, E., \& Amir, E. (1996). The information content of the president's letter to shareholders. Journal of Business Finance \& Accounting, 23(8), 1157-1182. https://doi.org/10.1111/j.1468-5957.1996.tb01163.x

Abrahamson, E., \& Park, C. (1994). Concealment of negative organizational outcomes: an agency theory perspective. Academy of Management Journal, 37(5), 1302-1334. https://doi.org/10.2307/256674

Adelberg, A. H. (1979). Narrative disclosures contained in financial reports: means of communication or manipulation? Accounting and Business Research, 9(35), 179-190. https://doi.org/10.1080/00014788.1979.9729157

Aerts, W. (2001). Inertia in the attributional content of annual accounting narratives. European Accounting Review, 10(1), 3-32. https://doi.org/10.1080/09638180122562

Aerts, W. (2005). Picking up the pieces: impression management in the retrospective attributional framing of accounting outcomes. Accounting, Organizations and Society, 30(6), 493-517. https://doi.org/10.1016/j.aos.2004.07.001

Aerts, W., \& Yan, B. (2017). Rhetorical impression management in the letter to shareholders and institutional setting. Accounting, Auditing \& Accountability Journal, 30(2), 404-432. https://doi.org/10.1108/AAAJ-01-2015-1916

Allee, K. D., \& Deangelis, M. D. (2015). The structure of voluntary disclosure narratives: evidence from tone dispersion. Journal of Accounting Research, 53(2), 241-274. https://doi.org/10.1111/1475-679X.12072

Asay, H. S., Libby, R., \& Rennekamp, K. (2018). Firm performance, reporting goals, and language choices in narrative disclosures. Journal of Accounting and Economics, 65(2-3), 380-398. https://doi.org/10.1016/j.jacceco.2018.02.002

Barnett, A., \& Leoffler, K. (1979). Readability of accounting and auditing messages. Journal of Business Communication, 16(3), 49-59. https://doi.org/10.1177/002194367901600305

Beattie, V. (2014). Accounting narratives and the narrative turn in accounting research: Issues, theory, methodology, methods and a research framework. The British Accounting Review, 46(2), 111-134. https://doi.org/10.1016/j.bar.2014.05.001

Beattie, V. A., \& Jones, M. J. (2000). Changing graph use in corporate annual reports: a time-series analysis. Contemporary Accounting Research, 17(2), 213-226. https://doi.org/10.1506/AAT8-3CGL-3J94-PH4F

Beattie, V., Dhanani, A., \& Jones, M. J. (2008). Investigating presentational change in U.K. Annual reports: A longitudinal perspective. Journal of Business Communication, 45(2), 181-222. https://doi.org/10.1177/0021943607313993

Beattie, V., McInnes, B., \& Fearnley, S. (2004). A methodology for analysing and evaluating narratives in annual reports: a comprehensive descriptive profile and metrics for disclosure quality attributes. Accounting Forum, 28(3), 205-236. https://doi.org/10.1016/j.accfor.2004.07.001

Beneish, M. D. (2001). Earnings management: a perspective. Managerial Finance, 27(12), 3-17.

https://doi.org/10.1108/03074350110767411 
Bhana, N. (2009). The chairman's statements and annual reports: Are they reporting the same company performance to investors? Investment Analysts Journal, 38(70), 32-46.

https://doi.org/10.1080/10293523.2009.11082513

Bloomfield, R. (2008). Discussion of "Annual report readability, current earnings, and earnings persistence". Journal of Accounting and Economics, 45(2-3), 248-252.

https://doi.org/10.1016/j.jacceco.2008.04.002

Bloomfield, R. J. (2002). The "Incomplete Revelation Hypothesis" and financial reporting. Accounting Horizons, 16(3), 233-243. https://doi.org/10.2308/acch.2002.16.3.233

Bolino, M., Long, D., \& Turnley, W. (2016). Impression management in organizations: critical questions, answers, and areas for future research. Annual Review of Organizational Psychology and Organizational Behavior, 3(1), 377-406. https://doi.org/10.1146/annurev-orgpsych-041015-062337

Brennan, N. M., Guillamon-Saorin, E., \& Pierce, A. (2009). Methodological insights: impression management: developing and illustrating a scheme of analysis for narrative disclosures - a methodological note. Accounting, Auditing \& Accountability Journal, 22(5), 789-832.

https://doi.org/10.1108/09513570910966379

Breton, G., \& Taffler, R. J. (2001). Accounting information and analyst stock recommendation decisions: a content analysis approach. Accounting and Business Research, 31(2), 91-101. https://doi.org/10.1080/00014788.2001.9729604

Burgstahler, D., \& Eames, M. (2006). Management of earnings and analysts' forecasts to achieve zero and small positive earnings surprises. Journal of Business Finance and Accounting, 33(5-6), 633-652.

https://doi.org/10.1111/j.1468-5957.2006.00630.x

Clatworthy, M., \& Jones, M. J. (2001). The effect of thematic structure on the variability of annual report readability. Accounting, Auditing \& Accountability Journal, 14(3), 311-326. https://doi.org/10.1108/09513570110399890

Clatworthy, M., \& Jones, M. J. (2006). Differential patterns of textual characteristics and company performance in the chairman's statement. Accounting, Auditing \& Accountability Journal, 19(4), 493-511. https://doi.org/10.1108/09513570610679100

Courtis, J. K. (1995). Readability of annual reports: Western versus Asian evidence. Accounting, Auditing \& Accountability Journal, 8(2), 4-17. https://doi.org/10.1108/09513579510086795

Courtis, J. K. (1998). Annual report readability variability: tests of the obfuscation hypothesis. Accounting, Auditing \& Accountability Journal, 11(4), 459-472.

https://doi.org/10.1108/09513579810231457

Courtis, J. K. (2004). Corporate report obfuscation: artefact or phenomenon? The British Accounting Review, 36(3), 291-312. https://doi.org/10.1016/j.bar.2004.03.005

Davidson, W. N., Jiraporn, P. \& Nemec, C. (2004). Earnings management following duality-creating successions: ethnostatistics, impression management, and agency theory. Academy of Management Journal, 47(2), 267-275. https://doi.org/10.2307/20159577

Elliott, W. B. (2006). Are investors influenced by pro forma emphasis and reconciliations in earnings announcements? The Accounting Review, 81(1), 113-133. https://doi.org/10.2308/accr.2006.81.1.113

Falschlunger, L. M., Eisl, Ch., Losbichler, H., \& Greil, A. M. (2015). Impression management in annual reports of the largest European companies. Journal of Applied Accounting Research, 16(3), 383-399.

https://doi.org/10.1108/JAAR-10-2014-0109

Fleming, A. S., Hermanson, D. R., Kranacher, M.-J., \& Riley, R. A. Jr. (2016). Financial reporting fraud: public and private companies. Journal of Forensic Accounting Research, 1(1), A27-A41. https://doi.org/10.2308/jfar-51475

Hadro, D., Klimczak, K. M., \& Pauka, M. (2017). Impression management in letters to shareholders: evidence from Poland. Accounting in Europe, 14(3), 305-330.

https://doi.org/10.1080/17449480.2017.1378428

Heath, R. L., \& Phelps, G. (1984). Annual reports II: Readability of reports vs. business press. Public Relations Review, 10(2), 56-62. https://doi.org/10.1016/S0363-8111(84)80007-7

Hogan, C. E., Rezaee, Z., Riley, R. A. Jr., \& Velury, U. K. (2008). Financial statement fraud: insights from the academic literature. AUDITING: A Journal of Practice \& Theory, 27(2), 231-252.

https://doi.org/10.2308/aud.2008.27.2.231

Jones, M. J. (1988). A longitudinal study of the readability of the chairman's narratives in the corporate reports of a UK company. Accounting and Business Research, 18(72), 297-305. https://doi.org/10.1080/00014788.1988.9729377

Jones, M., \& Smith, M. (2014). Traditional and alternative methods of measuring the understandability of accounting narratives. Accounting, Auditing \& Accountability Journal, 27(1), 183-208. https://doi.org/10.1108/AAAJ-04-2013-1314

Keusch, T., Bollen, L. H. H., \& Hassink, H. F. D. (2012). Selfserving bias in annual report narratives: an empirical analysis of the impact of economic crises. European Accounting Review, 21(3), 1-26.

https://doi.org/10.1080/09638180.2011.641729

Kohut, G. F., \& Segars, A. H. (1992). The president's letter to stockholders: an examination of corporate communication strategy. Journal of Business Communication, 29(1), 7-21. https://doi.org/10.1177/002194369202900101

Leary, M. R., \& Kowalski, R. M. (1990). Impression management: A literature review and two-component model. Psychological Bulletin, 107(1), 34-47. https://doi.org/10.1037//0033-2909.107.1.34

Lehavy, R., Li, F., \& Merkley, K. (2011). The effect of annual report readability on analyst following and the properties of their earnings forecasts. The Accounting Review, 86(3), 10871115. https://doi.org/10.2308/accr.00000043

Li, F. (2008). Annual report readability, current earnings, and earnings persistence. Journal of Accounting and Economics, 45(2-3), 221-247. https://doi.org/10.1016/j.jacceco.2008.02.003

Lim, E. K., Chalmers, K., \& Hanlon, D. (2018). The influence of business strategy on annual report readability. Journal of Accounting and Public Policy, 37(1), 65-81. https://doi.org/10.1016/j.jaccpubpol.2018.01.003

Linsley, P. M., \& Lawrence, M. J. (2007). Risk reporting by the largest UK companies: readability and lack of obfuscation. Accounting, Auditing \& Accountability Journal, 20(4), 620627. https://doi.org/10.1108/09513570710762601

Lo, K., Ramos, F., \& Rogo, R. (2017). Earnings management and annual report readability. Journal of Accounting and Economics, 63(1), 1-25. https://doi.org/10.1016/j.jacceco.2016.09.002

Loughran, T., \& Mcdonald, B. (2014). Measuring readability in financial disclosures. The Journal of Finance, 69(4), 16431671. https://doi.org/10.1111/jofi.12162

Luo, J., Li, X., \& Chen, H. (2018). Annual report readability and corporate agency costs. China Journal of Accounting Research, 11(3), 187-212. https://doi.org/10.1016/j.cjar.2018.04.001

Mäkelä, H., \& Laine, M. (2011). A CEO with many messages: Comparing the ideological representations provided by different corporate reports. Accounting Forum, 35(4), 217-231. https://doi.org/10.1016/j.accfor.2011.06.008 
Melis, A., \& Aresu, S. (2019). Analyst following, country's financial development, and the selective use of graphical information in corporate annual reports. International Journal of Business Communication.

https://doi.org/10.1177/2329488419829886

Merkl-Davies, D., \& Brennan, N. (2007). Discretionary disclosure strategies in corporate narratives: Incremental information or impression management? Journal of Accounting Literature, 26, 116-196.

Merkl-Davies, D. M., Brennan, N. M., \& McLeay, S. J. (2011). Impression management and retrospective sense-making in corporate narratives. Accounting, Auditing \& Accountability Journal, 24(3), 315-344. https://doi.org/10.1108/09513571111124036

Moffitt, K., \& Burns, M. (2009). What does that mean? Investigating obfuscation and readability cues as indicators of deception in fraudulent financial reports. In AMCIS 2009 Proceedings. https://aisel.aisnet.org/amcis2009/399

Moreno, A., \& Casasola, A. (2016). A readability evolution of narratives in annual reports. Journal of Business and Technical Communication, 30(2), 202-235. https://doi.org/10.1177/1050651915620233

Moreno, A., Jones, M. J., \& Quinn, M. (2019). A longitudinal study of the textual characteristics in the chairman's statements of Guinness. Accounting, Auditing \& Accountability Journal, ahead-of-print). https://doi.org/10.1108/AAAJ-01-2018-3308

NASDAQ OMX Stockholm. (n.d.). http://www.nasdaqomxnordic.com

Neu, D. (1991). Trust, impression management and the public accounting profession. Critical Perspectives on Accounting, 2(3), 295-313. https://doi.org/10.1016/1045-2354(91)90015-6

Neu, D., Warsame, H., \& Pedwell, K. (1998). Managing public impressions: environmental disclosures in annual reports. Accounting, Organizations and Society, 23(3), 265-282. https://doi.org/10.1016/S0361-3682(97)00008-1

Omar, N., Rahman, R. A., Danbatta, B. L., \& Sulaiman, S. (2014). Management disclosure and earnings management practices in reducing the implication risk. Procedia - Social and Behavioral Sciences, 145, 88-96. https://doi.org/10.1016/j.sbspro.2014.06.014

Rezaee, Z. (2005). Causes, consequences, and deterence of financial statement fraud. Critical Perspectives on Accounting, 16(3), 277-298. https://doi.org/10.1016/S1045-2354(03)00072-8

Russell, M. (2015). Continuous disclosure and information asymmetry. Accounting Research Journal, 28(2), 195-224. https://doi.org/10.1108/ARJ-11-2013-0085

Rutherford, B. A. (2003). Obfuscation, textual complexity and the role of regulated narrative accounting disclosure in corporate governance. Journal of Management and Governance, 7(2), 187-210. https://doi.org/10.1023/A:1023647615279

Rutherford, B. A. (2005). Genre analysis of corporate annual report narratives: a corpus linguistics-based approach. Journal of Business Communication, 42(4), 349-378. https://doi.org/10.1177/0021943605279244

Rutherford, B. A. (2016). The struggle to fabricate accounting narrative obfuscation. Qualitative Research in Accounting \& Management, 13(1), 57-85.

https://doi.org/10.1108/QRAM-06-2015-0060

Segars, A. H., \& Kohut, G. F. (2001). Strategic communication through the world wide web: an empirical model of effective- ness in the CEO's letter to shareholders. Journal of Management Studies, 38(4), 535-556.

https://doi.org/10.1111/1467-6486.00248

Skinner, D. J. (1994). Why firms voluntarily disclose bad news. Journal of Accounting Research, 32(1), 38.

https://doi.org/10.2307/2491386

Smith, M., \& Taffler, R. (1992). Readability and understandability: different measures of the textual complexity of accounting narrative. Accounting, Auditing \& Accountability Journal, 5(4). https://doi.org/10.1108/09513579210019549

Smith, M., \& Taffler, R. (1995). The incremental effect of narrative accounting information in corporate annual reports. Journal of Business Finance \& Accounting, 22(8), 1195-1210. https://doi.org/10.1111/j.1468-5957.1995.tb00901.x

Smith, M., \& Taffler, R. J. (2000). The chairman's statement - A content analysis of discretionary narrative disclosures. Accounting, Auditing \& Accountability Journal, 13(5), 624-647. https://doi.org/10.1108/09513570010353738

Stanton, P., \& Stanton, J. (2002). Corporate annual reports: research perspectives used. Accounting, Auditing \& Accountability Journal, 15(4), 478-500.

https://doi.org/10.1108/09513570210440568

Stone, G. W., \& Parker, L. (2016). A comment on "The struggle to fabricate accounting narrative obfuscation: an actornetwork-theoretic analysis of a failing project. Qualitative Research in Accounting \& Management, 13(1), 86-89. https://doi.org/10.1108/QRAM-01-2016-0003

Subramanian, R., Insley, R. G., \& Blackwell, R. D. (1993). Performance and readability: a comparison of annual reports of profitable and unprofitable corporations. Journal of Business Communication, 30(1), 49-61. https://doi.org/10.1177/002194369303000103

Sydserff, R., \& Weetman, P. (1999). A texture index for evaluating accounting narratives. Accounting, Auditing \& Accountability Journal, 12(4), 459-488. https://doi.org/10.1108/09513579910283503

Sydserff, R., \& Weetman, P. (2002). Developments in content analysis: a transitivity index and DICTION scores. Accounting, Auditing \& Accountability Journal, 15(4), 523-545. https://doi.org/10.1108/09513570210440586

Telseth, F., \& Halldorsson, V. (2019). The success culture of Nordic football: the cases of the national men's teams of Norway in the 1990s and Iceland in the 2010s. Sport in Society, 22(4), 689-703. https://doi.org/10.1080/17430437.2017.1390928

Thomas, J. (1997). Discourse in the marketplace: the making of meaning in annual reports. Journal of Business Communication, 34(1), 47-66. https://doi.org/10.1177/002194369703400103

Verrecchia, R. E. (2001). Essays on disclosure. Journal of Accounting and Economics, 32(1-3), 97-180. https://doi.org/10.1016/S0165-4101(01)00025-8

Wang, J. (2016). Literature review on the impression management in corporate information disclosure. Modern Economy, 07(06), 725-731. https://doi.org/10.4236/me.2016.76076

Yan, B., Aerts, W., \& Thewissen, J. (2019). The informativeness of impression management - financial analysts and rhetorical style of CEO letters. Pacific Accounting Review. https://doi.org/10.1108/PAR-09-2017-0063 